\title{
PENGARUH APLIKASI ISI RUMEN SAPI DAN KELELAWAR TERHADAP INTENSITAS PENYAKIT AKAR GADA (Plasmodiophora brassicae Wor.) PADA TANAMAN PAKCOY (Brassica rapa L.)
}

\section{THE INFLUENCE OF COW AND BAT RUMENS APPLICATION ON THE INTENSITY OF CLUBROOT DISEASE (Plasmodiophora brassicae Wor.) PAKCOY PLANT (Brassica rapa L.)}

\author{
Muhammad Nurdin, Reza Baharsyah*, Yohannes Cahya Ginting dan Suskandini Ratih Dirmawati \\ Jurusan Agroteknologi, Fakultas Pertanian, Universitas Lampung \\ J1 Sumantri Brojonegoro 1, Bandar Lampung 35145, Indonesia \\ *Email: Rezzabaharsyah@gmail.com.
}

\begin{abstract}
Clubroot diseases were caused by the pathogen Plasmodiophora brassicaeWor. which causes the emergence of nodules that combined into a mace-like elongated swelling on the roots. There's a lot of way in which this disease can be controlled, one of them is by usage of fungicide. However, intensive usage of inorganic fungicide can lead into vary of problems, namely pollution of soil and water. Therefore need another alternative control, one option is to use cow and bat rumens. This research was conducted to determine the effect of the application of cow and bat rumens in suppressing the clubroot diseases in pakcoy plants. The hypothesis of this study is that there's an influence in the application of cow and bat rumens to the intensity of clubroot in pakcoy plants. This research was conducted on April 3 to May 28, 2019 in the greenhouse of the Faculty of Agriculture, University of Lampung. The variables used in this study were the occurrence of disease, disease severity, plant fresh weight and root fresh weight. This research was arranged in a Randomized Block Design with control treatment (P0), cow rumen (P1) and bat rumen (P2). The test also concurrently as a group. Data were processed using analysis of variance and tested with LSD at 5\% significance level. The results showed that the effect of the cow and bat rumens treatment was significantly different from the control on the variables of occurrence disease, but not significantly different from the controls on the observed variables of disease severity, plant fresh weight and root fresh weight.
\end{abstract}

Keywords: Clubroot, pakcoy, Plasmodiophora brassicae.

\begin{abstract}
ABSTRAK
Penyakit akar gada disebabkan oleh patogen Plasmodiophora brassicae Wor.yang menimbulkan gejala berupa bintil-bintil pada akar yang bersatu menjadi bengkak memanjang yang mirip dengan gada. Pengendalian penyakit akar gada salah satunya dapat menggunakan fungisida.Penggunaan fungisida anorganik secara intensif ternyata dapat menimbulkan berbagai masalah yaitu pencemaran tanah dan air. Oleh karena ituperlu alteratiflain yaitu menggunakan isi rumen sapi dan rumen kelelawar. Penelitian ini dilakukan untuk mengetahui pengaruh aplikasi isi rumen sapi dan rumen kelelawar dalam menekan intensitas penyakit akar gada pada tanaman pakcoy. Hipotesis
\end{abstract}


penelitian ini adalah terdapat pengaruh pemberian rumen sapi dan rumen kelelawar terhadap intensitas penyakit akar gada pada tanaman pakcoy. Penelitian ini dilakukan pada 3 April sampai 28 Mei 2019 di rumah kaca Fakultas Pertanian Universitas Lampung. Peubah yang digunakan dalam penelitian ini adalah keterjadian penyakit, keparahan penyakit, bobot segar tanaman dan bobot segar akar.Penelitian ini disusun dalam Rancangan Acak Kelompok dengan perlakuan kontrol (P0), rumen sapi (P1) dan rumen kelawar (P2). Ulangan merangkap lebih dan sekaligus sebagai kelompok. Data diolah menggunakan analisis ragam dan diuji dengan BNT pada taraf nyata 5\%. Hasil penelitian menunjukkan bahwa pengaruh perlakuan rumen sapi dan rumen kelelawar berbeda nyata dengan kontrol pada variabel keterjadian penyakit, namun tidak berbeda nyata dengan kontrol pada variabel pengamatan keparahan penyakit, bobot segar tanaman dan bobot segar akar.

Kata kunci: Akar gada, pakcoy, Plasmodiophora brassicae.

\section{PENDAHULUAN}

Sawi merupakan jenis sayuran yang banyak digemari oleh masyarakat. Tanaman sawi adalah tanaman semusim kelompok dari genus Brassica yang memiliki beberapa jenis yaitu salah satunya sawi huma atau dikenal dengan pakcoy (Brassica rapaL). Tanaman pakcoy termasuk jenis yang paling banyak dibudidayakan dan bernilai ekonomi tinggi.

Tanaman pakcoy dapat tumbuh baik di tempat yang berhawa panas maupun berhawa dingin, sehingga dapat diusahakan dari dataran rendah maupun dataran tinggi.Umumnya dibudidayakan pada daerah yang mempunyai ketinggian 100-500m di atas permukaan laut(dpl).Tanaman pakcoyjuga biasa ditanaman pada saat musim kemarau asalkan ketersedian air yang cukup untuk memenuhi kebutuhan penyiraman tanaman (Nazarudin, 1999).

Pakcoy tergolong kedalam kelompok sayuran yang paling populer di kalangan masyarakat.Namun keberadaannya tidak terlepas dari serangan penyakit tanaman yang dapat menurunkan hasil produksi baik kualitas maupun kuantitas.Produktivitas tanaman pakcoy di Indonesia masih dapat ditingkatkan apabila permasalahan yang terjadi pada usahatani komoditas tersebut dapat dikurangi, seperti carabudidaya yang baik dan benar serta pengelolaan organisme pengganggu tanaman (OPT) yang tepat sasaran, sehingga kehilangan hasil dapat ditekan.

Salah satu penyakitpada tanaman pakcoy adalah penyakit akar gadayang disebabkan olehPlasmodiophora brassicaeWor.yang menimbulkan gejala berupa bintil-bintil pada akar yang bersatu menjadi bengkak memanjang yang mirip dengan batang (gada), sehingga dinamakan penyakit akar gada (Semangun, 2007).Akar gada (clubroot) di Indonesia dikenal pula dengannama-nama: akar bengkak, akar kaki gajah, atau akar pekuk.

Penyakit akar gadamerupakan salah satu penyakit tular tanah yang sangat penting pada tanaman kubis-kubisan (Brassica spp.) di seluruh dunia.Di Indonesia akar gada merupakan penyakit utama yang menyerang kubis-kubisan. Kerugian yang ditimbulkannya dapat sangat besar, karena pertanaman dapat sama sekali tidak memberikan hasilyang dapat dijual (Agrios, 1996).Apabila suatu lahan telah terinfeksi oleh penyakit ini, maka spora patogen ini 
dapat bertahan hingga bertahun-tahun, walaupun tidak ditanami kubis-kubisan selama kurun waktu tersebut. Menurut Semangun (2007), jamur dapat hidup selama 10 tahun atau lebih, meskipun tidak ada tumbuhan inang.

Pengendalian akar gada pada sayuran kubiskubisan pada umumnya melalui rotasi dengan tanaman bukan kubis-kubisan, pemberian pestisida dan penambahan kapur untuk meningkatkan $\mathrm{pH}$ tanah.Rotasi dengan tanaman bukan inang biasanya relatife efektifuntuk menekan akar gada, namun dalam jangka panjang hanya memberikan dampak kecil, karena spora $P$. brassicae bertahan hidup dalam bentuk spora istirahat. Pengaplikasian pestisida kimia secara terus menerus dapat merusak lingkungan, utamanya ekosistem tanah. Oleh karena itu diupayakan penggunaan agensia hayati berupa mikroba antagonis.

Mikroba antagonis atau agen pengendali hayati penyakit tanaman adalah jasad renik baik berupa bakteri, jamur, aktinomisetes maupun virus yang dapat menekan, menghambat atau memusnahkan organisme pengganggu pada tanaman.Mikroba antagonis secara langsung atau tidak langsung dapat mengontrol perkembangan patogen tular tanah.Di dalam rumen ternak ruminansia terdapat berbagai mikroorganisme yang terdiri dari protozoa, bakteri dan jamur yang memiliki berbagai fungsi, diharapkan salah satunya sebagai agen hayati pengendalian penyakit tanaman. Penelitian ini dilakukan dengan tujuan untuk mengetahui pengaruh aplikasi isi rumen sapidan rumen kelelawar terhadap intensitas penyakit akar gada pada tanaman pakcoy serta mengetahui apakah rumen sapi lebih baik dari pada rumen kelelawar

\section{BAHAN DAN METODE}

Penelitian ini dilaksanakan di Rumah Kaca Fakultas Pertanian Universitas Lampung dari 3 April sampai dengan 28 Mei 2019. Percobaan ini dilakukan dengan rancangan acak kelompok (RAK) dengan tiga perlakuan.Tiga perlakuan tersebut adalah sebagai berikut; tanpa rumen $(\mathrm{P} 0)$, rumen sapi $(\mathrm{P} 1)$, rumen kelelawar (P2). Masing-masing perlakuan diulang sebanyak tiga kali. Data yang diperoleh diolah dengan Analisis Ragam dan selanjutnya diuji dengan BNT pada taraf nyata $5 \%$.

Perlakuan dalam penelitian ini yaitu penggunaan fermentasi isi rumen sapi dan rumen kelelawar sebagai pengendalian penyakit akar gada. Cairan rumen yang digunakan berasal dari proses perbanyakan mikroba yang berasal dari isi rumen sapi atau kelelawar yang dicampur dengan media air ditambah dengan gula merah. Media tersebut berupagula merah sebanyak 250 g yang dilarutkan ke dalam $750 \mathrm{ml}$ air dengan cara direbus. Selanjutnya air gula dimasukkan kedalam botol plastik 1,5 liter hingga $\pm \frac{3}{4}$ bagian. Rumen sapi diambil disalah satu rumah pemotongan hewan yang berada di desa Kaliwungu kecamatan Kalirejo.Sedangkan Kelelawar yang digunakan ditangkap menggunakan jaring langsung dari alam di desa Poncowarno kecamatan Kalirejo. Isi rumen diambil satu sendok untuk dimasukkan ke dalam botol yang berisi cairan gula selanjutnya botol ditutup rapat dan dikocok. Cairan rumen disimpan pada suhu ruang hingga dua minggu dan sesekali dibuka tutup botol sebentar dan dikocok.

Bobot segar tanaman diukur dengan menimbang tamanan tanpa bagian akar. Sedangkan bobot segar akar diukur dengan menimbang bagian akar. 
Penimbangan dilakukan setelah dilakukan pemanenan atau 6 minggu setelah tanam. Rumus untuk menghitung keterjadian penyakit digunakan rumus sebagai berikut:

$$
\mathrm{KiP}=\frac{n}{\mathrm{~N}} \times 100 \%
$$

Keterangan:

KiP $=$ Keterjadian penyakit

$\mathrm{n} \quad=$ Jumlah tanaman yang terserang patogen

$\mathrm{N} \quad=$ Total tanaman yang diamati

Rumus untuk menghitung keparahan penyakit sebagai berikut:

$$
\mathrm{PP}=\sum \frac{(n x v)}{N x V} x 100
$$

Keterangan :

$\mathrm{PP} \quad=$ Keparahan penyakit

$\mathrm{n} \quad=$ Jumlah tanaman yang terserang dengan skor kerusakan

$\mathrm{V} \quad=$ Nilai skor kerusakan

$\mathrm{N} \quad=$ Jumlah tanaman yang diamati

$\mathrm{V} \quad=$ Nilai skor tertinggi

Kriteria nilai skor kerusakan ialah sebagai berikut:

$1=$ Tanaman sehat, 2 = Tanaman sakit dan $3=$ Tanaman mati sebelum panen

\section{HASIL DAN PEMBAHASAN}

\section{Hasil Penelitian}

Hasil penelitian menunjukkanbahwa pengaruh perlakuan rumen sapi dan rumen kelelawar berbeda nyata dengan kontrol pada variabel keterjadian penyakit, namun tidak berbeda nyatadengan kontrol pada variabel pengamatan keparahan penyakit,bobot segar tanaman dan bobot segar akar.

\subsubsection{Keterjadian penyakit}

Hasil penelitian menunjukkan bahwa pada tiap perlakuan berpengaruh nyata dalam variabel keterjadian penyakit. Rata-rata keterjadian penyakit terendah pada perlakuan rumen sapi yaitu $74,00 \%$. Sementara pada perlakuan rumen kelelawar rata-rata keterjadian penyakit $81,22 \%$. Lebih baik dari pada perlakuan kontrol rata-rata keterjadian penyakit mencapai 100\% (Tabel 1).

\subsubsection{Keparahan peyakit}

Hasil analisis statistika menunjukkan bahwa fermentasi isi rumen sapi dan rumen kelelawar tidak berpengaruh nyata terhadap keparahan penyakit akar gada pada tanaman pakcoy. Pada perlakuan tanpa rumen rata-rata keparahan penyakit sebesar 76,55\%, sedangkan rata-rata keparahan penyakit pada perlakuan rumen sapi sebesar $64,20 \%$ dan pada perlakuan rumen kelelawar rata-rata keparahan penyakit sebesar 69,14\% (Gambar 1).

\subsubsection{Bobot segar tanaman dan bobot segar akar}

Hasil penelitian menunjukkan bahwa pengaruh perlakuan rumen sapi dan rumen kelelawar tidak berbeda nyata dengan kontrol dalam hal bobot segar tanaman dan bobot segar akar (Tabel 2).

\section{Pembahasan}

Hasil pengamatan menunjukkan bahwa tanaman pakcoy yang sehat di lapangan daunnya tetap hijau, tidak layu, helaian daun normal dan tegak. Sedangkan tanaman pakcoy yang terinfeksi

Tabel 1. Keterjadian penyakit akar gada pada tanaman pakcoy

\begin{tabular}{lc}
\hline \multicolumn{1}{c}{ Perlakuan } & Rata-rata \\
\hline Kontrol & $100.00 \mathrm{c}$ \\
Rumen Sapi & $74.08 \mathrm{a}$ \\
Rumen Kelelawar & $81.48 \mathrm{~b}$ \\
\hline
\end{tabular}

Keterangan: Angka sekolom yang diikuti huruf yang tidak sama berarti berbeda nyata pada uji BNT 5\%. 
Tabel 2. Berat Segar Tanaman dan Berat Segar Akar akar gada pada tanaman pakcoy

\begin{tabular}{lcc}
\hline Perlakuan & $\begin{array}{c}\text { Rerata Bobot } \\
\text { Segar Tanaman }(\mathrm{g})\end{array}$ & $\begin{array}{c}\text { Rerata Bobot } \\
\text { Segar Akar }(\mathrm{g})\end{array}$ \\
\hline Kontrol & 3,46 & 0,73 \\
Rumen Sapi & 4,88 & 0,45 \\
Rumen & 4,70 & 0,33 \\
Kelelawar & & \\
\hline
\end{tabular}

Plasmodiophora brassicae pada siang hari akan terlihat layu. Tanaman pakcoy yang sakit apabila dicabut akarnya mengalami pembengkakkan. Hal ini berarti transportasi air melalui xylem terganggu sehingga tanaman layu. Menurut Semangun (2007) rusaknya susunan jaringan akar menyebabkan rusaknya jaringan pengangkutan, sehingga pengangkutan air dan hara tanah terganggu. Tanaman yang layu tampak merana, daunya berwarna hijau kelabu.

Sebagian akar tanaman pakcoy yang bengkakbengkak berubah warna menjadi coklat dan kehitaman yang diduga akibat matinya jaringan tersebut. Pengamatan mikrokopis terhadap akar tanaman pakcoy yang sakit memperlihatkan jamur $P$. brassicae yang berupa plasmodiumberbentuk bulat dan agak lonjong berada di berada dalam sel tanaman inang (Gambar 2).
Penyakit akar gada akan selalu jadi faktor pembatas dalam budidaya tanaman pakcoy bila suatu area telah terkontaminasi. Pengaplikasian isi rumen sapi dan rumen kelelawar setiap minggunya disekitar area perakaran tanaman pakcoy berpengaruh nyata dalam mengurangi keterjadian penyakit akar gada namun tidak berpengaruh nyata pada keparahan penyakit tanaman. Tingkat keterjadian penyakit tertinggi adalah pada kontrol atau tanpa perlakuan rumen yaitu ratarata sebesar $100 \%$. Keterjadian terendah adalah pada aplikasi rumen sapi dengan rata-rata sebesar 74,08\%. Hasil analisis statistika menunjukkan bahwa fermentasi isi rumen sapi dan rumen kelelawar tidak berpengaruh nyata terhadap keparahan penyakit akar gada. Ratarata keparahan penyakit terbesar yaitu $76,55 \%$ pada kontrol, sedangkan rata-rata keparahan penyakit terkecil pada perlakuan rumen sapi sebesar $64,20 \%$.

Hal tersebut tidak sama dengan pernyataan Sutanto (2002),yaitu bahwa penambahan bahan organik memberikan pengaruh pada sifat biologi tanah yang akan berdampak meningkatkan keragaman jamur, bakteri, mikro flora, dan mikro fauna tanah lainnya yang menguntungkan bagi tanaman.Patogen sukar melakukan

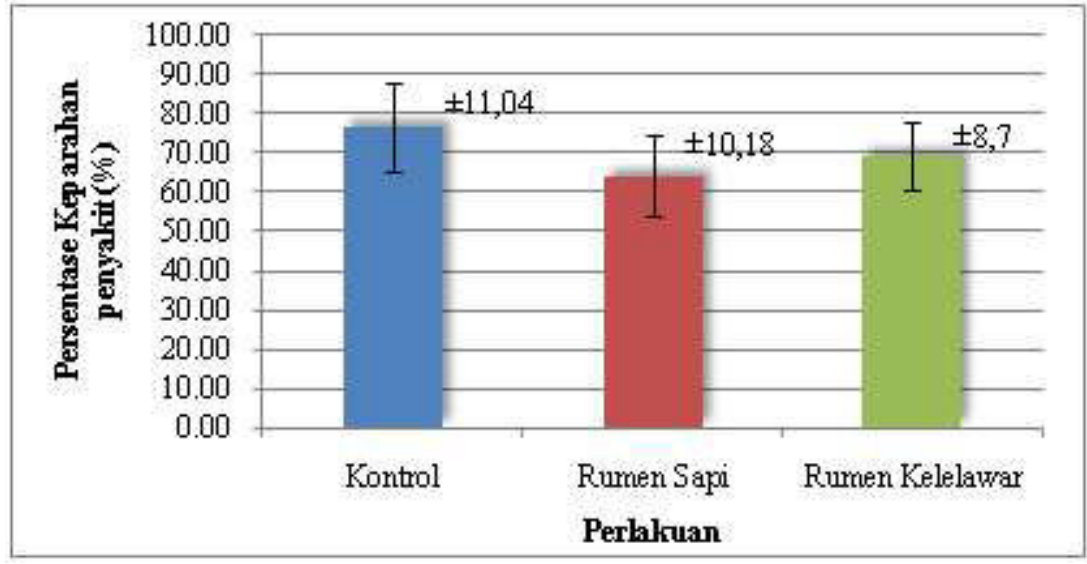

Gambar 1. Keparahan penyakit akar gada pada tanaman pakcoy 


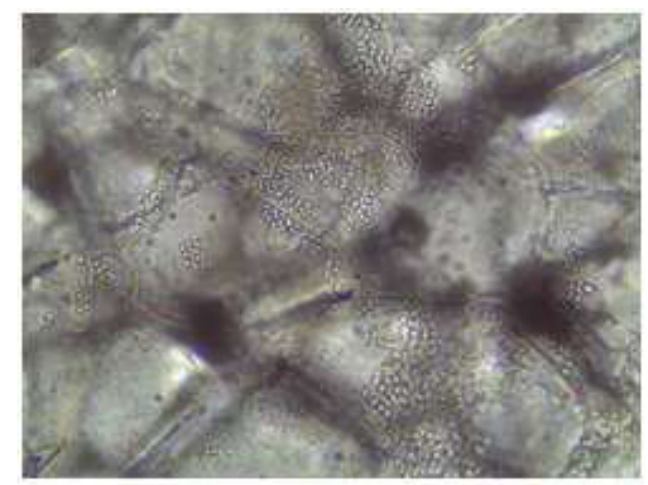

Gambar 2. Hasil mikroskopis sel akar terinfeksi akar gada

penetrasi apabila sistem perakaran didominasi oleh berbagai jenis miroba. Penambahan bahan organik seperti fermentasi isi rumen sapi dan rumen kelelawar pada budidaya pakcoy dapat meningkatkan keragaman mikroba.

Rumen ternak ruminansia (sapi, kerbau, kambing dan domba) mengandung populasi mikroba yang cukup banyak jumlahnya, baik jenis bakteri,jamur maupun protozoa (Tillman dkk., 1991). Populasi bakteri pada usus besar dan feses ternak ruminansia termasuk golongan spesies bakteri yang juga terdapat di dalam rumen, yaitu termasuk dalam famili Bacteriodes, Selenomunus ruminantium, Streptococcus bovis, Lachnospira, Ruminococcus dan Succinivibrio (Arora, 1989).

Kandungan fermentasi rumen kelelawar termasuk golongan spesies mikroba yang juga terdapat pada guano kelelawar. Komposisi utama guano kelelawar terdiri atas kitin (Gross dkk.,2004).Bakteri guano kelelawar diduga bersifat kitinolistik. Xiao dkk (2005) melaporkan bahwa bakteri yang terdapat dalam guano penguin di Amerika sebagian besar bersifat kitinolitik, yaitu mampu menghasilkan atau memproduksi kitinase.Peranan kitinase pada ketahanan tanaman terhadap serangan patogen dapat melalui dua cara, yaitu pertama kitinase menghambat pertumbuhan jamur dan kedua adalah aktivitas kitinase berakibat pelepasan elicitor endogen yang kemudian memicu reaksi ketahanan sistemik pada inang sehingga terjadi penurunan atau penghambatan invasi patogen (Oku, 1994). Sehingga adanya bakteri penghasil kitinase dari fermentasirumen kelelawar dapat berpengaruh terhadap keterjadian penyakit . brassicae.

Penggunaan fermentasi isi rumen sapi dan rumen kelelawar yang diaplikasikan setiap minggu tidak menunjukkan adanya pengaruh dalam keparahan penyakit akar gada di lapang.Hal ini kemungkinan diduga kurangnya konsentrasi rumen sapi dan rumen kelelawar yang digunakan.Pemberian aplikasi rumen sapi dan rumen kelelawar tidak berbeda nyata dalam menurunkan bobot segar akar pakcoy. Rata-rata bobot segar akar tertinggi yaitu pada perlakuan kontrol yaitu sebesar 1,01g. Hal tersebut dikarenakan terjadi pembengkakan pada daerah perakaran yang terinfeksi penyakit akar gada. Pada variabel pengamatan bobot segar daun + batang tanaman pakcoypemberian aplikasi rumen sapi dan rumen kelelawar tidak berbeda nyata. Rata-rata bobot segar daun + batang tanaman pakcoy tertinggi diperoleh yaitu: 3,87 g. Rendahnya bobot segar daun + batang tanaman pakcoy dalam penelitian ini selain karena kemungkinan adanya infeksi juga karena kondisi pencahayaan rumah kaca yang digunakan kurang optimal. Sehingga proses fotosintesis pada tanaman tidak optimum. Hal tersebut terjadi karena pembengkakan pada daerah perkakaran akan mengakibatkan fungsi akar terganggu sehingga suplai air untuk fotosintesis tidak mencukupi; yang pada akhirnya pertumbuhan tanaman tidak optimal. Pracaya (2005) menyatakan 
bahwa pertumbuhan yang tidak teratur mengakibatkan jaringan pengangkut air jadi terganggu, sehingga aliran air ke seluruh tubuh tanaman berkurang sehingga tanaman jadi layu dan kerdil.Menurut Sitompul dan Guritno (1995),peranan akar terhadap pertumbuhan tanaman sama pentingnya dengan tajuk.Sebagai gambaran, jika tajuk berfungsi untuk menyediakan karbohidrat dan energi melalui proses fotosintesis, maka akar berfungsi menyediakan unsur hara dan air yang diperlukan dalam proses metabolisme tanaman.

\section{KESIMPULAN}

Pengaplikasian isi rumen sapi dan rumen kelelawarberbeda nyata dengan kontrol pada variabel keterjadian penyakit, namun tidak berbeda nyata dengan kontrol pada variabel keparahan penyakit.Semua tanaman pada perlakuan kontrol terinfeksi penyakit akar gada, sementara pada perlakuan rumen sapi dan rumen kelelawar ada tanaman yang tidak terinfeksi, masing-masing terdapat $25,92 \%$ dan $18,52 \%$ tanaman sehat.

\section{UCAPAN TERIMAKASIH}

Ucapan terima kasih disampaikan kepada tim penelitian"Penggunaanfermentasi isi rumen sapi dan rumen kelelawar terhadap intensitas penyakit akar gada".

\section{DAFTAR PUSTAKA}

Agrios, G. N. 1996. Ilmu Penyakit Tumbuhan. Diterjemahkan oleh Busnia, M. Gadjah Mada University Press. Yogyakarta.713 hlm.
Arora, S. P. 1989. Pencernaan Mikrobia pada Ruminansia.Gadjah Mada University Press. Yogyakarta. $144 \mathrm{hlm}$.

Gross, R. S., Berna. F., Karkanas, Pdan Weiner, S. 2004. Bat guano and preservation ofarchaeological remains in cave sites. Journal Archaeoogical Science. 31: 1259-1272.

Nazaruddin.1999. Budi Daya dan Pengaturan Panen Sayuran Dataran Rendah. Penebar Swadaya. Jakarta.142 hlm.

Oku, H. 1994. Plant Pathogenesis and Disease Control. Lewis Publ. London. $208 \mathrm{hlm}$.

Pracaya. 2005. Hama dan Penyakit Tanaman. Penebar Swadaya. Jakarta.411 hlm.

Semangun, H. 2007. Penyakit-Penyakit Penting Tanaman Hortikultura di Indonesia. Gadjah Mada University Press. Yogyakarta. $845 \mathrm{hlm}$.

Sitompul, S. M. dan Guritno, B.1995.Analisis Pertumbuhan Tanaman. Gadjah Mada University Press. Yogyakarta.487 hlm.

Sutanto, R. 2002. Penerapan Pertanian Organik. Kanisius.Yogyakarta. $211 \mathrm{hlm}$

Tillman, A. D., Hartadi, H. Raksohadiprodjo, S. Prawirokusumo, S dan Lebdosukojo, S. 1991. Ilmu Makanan Ternak Dasar. Gadjah Mada University Press. Yogyakarta.

Xiao, X., Yin, X., Lin, J., Sun, L., You, Z., Wan, P., dan Wang, F. 2005. Chitinese genes in lake sediments of Ardley Island, Antartica. Applied and Environmental Microbiology 71 (12): 7904-7909. 